Стеценко С. П. [1; ORCID ID: 0000-0003-1439-3581], д.е.н., доцент, завідувач кафедри економіки будівництва,

Боліла Н. В. ${ }^{[1 ;}$ ORCID ID: 0000-0002-3353-8347], ст. викладач кафедри економіки будівництва Іванченко А. М. [2; ORCID ID: 0000-0002-1571-7173], к.е.н., доцент

${ }^{1}$ Київський національний університет будівництва і архітектури, м. Київ ${ }^{2}$ Національний університет водного господарства та природокористування, м. Рівне

\title{
АНАЛІТИЧНА ОЦІНКА І КОНТРОЛЬ ДЕБІТОРСЬКОЇ ЗАБОРГОВАНОСТІ БУДІВЕЛЬНИХ ПІДПРИЕМСТВ ЗА ДОПОМОГОЮ КОНТРОЛЬНИХ КАРТ
}

Робота присвячена проведенню аналізу і контролю дебіторської заборгованості підрядних будівельних підприємств на основі статистичних методів виробничого менеджменту. Для вирішення даного наукового завдання застосовано метод контрольних карт Шухарта, який базується на статистичній обробці даних щодо відхилень фактичних термінів і обсягів дебіторської заборгованості від їх планових значень. На основі аналізу характеру відхилень робляться висновки щодо характеру відхилень (випадкові чи ні) та приймаються управлінські рішення. Запропоновано проводити контроль дебіторської заборгованості підрядних будівельних підприємств у розрізі договірних цін у складі будівельних контрактів та додаткових угод (планові показники), фактичних надходжень i витрат та розрахунку планової i фактичної потреби підприємства в оборотних коштах. Контроль здійснюеться за показниками: терміни надходження грошових коштів та обсяги потреби в оборотних коштах за кожним будівельним контрактом. Такий підхід дозволяє диференційовано підходити до причин виникнення відхилень від плану. У роботі проаналізовано дебіторську заборгованість будівельного підприємства та запропоновано проводити контроль відхилень від плану за допомогою контрольних карт Шухарта, які дозволяють не тільки виявляти відхилення, але і визначати чинники впливу такі як випадкові і специфічні. Такий підхід дозволяє достовірно визначити фактори впливу, спрогнозувати ризики втрати фінансової стійкості та наслідки їх дії для економічної безпеки будівельного підприемства. Здійснено застосування відомого $\mathbf{i}$ широко розповсюдженого методу аналізу у новій області, а саме - для контролю дебіторської заборгованості. у процесі аналізу виявлено, що запропонований підхід дозволяє здійснювати контроль відхилень термінів і рівня дебіторської заборгованості, виявляти випадкові $i$ специфічні чинники, які впливають на відхилення від плану. Окремі результати та висновки статті можуть бути використані будівельними підприємствами, а також підприємствами інших галузей, у разі їх 


\section{відповідної адаптації, для аналізу і контролю дебіторської заборгованості.}

Ключові слова: дебіторська заборгованість; оборотні активи; будівельне підприємство; економічна стійкість; будівництво.

Постановка проблеми. Важливість контролю дебіторської заборгованості для збереження фінансової стійкості і економічної безпеки будівельних підприємств очевидна. Складність і багатостадійність інвестиційно-будівельного процесу, значна кількість учасників, нерівномірність грошових потоків вимагає від учасників будівництва враховувати різноманітні параметри будівельного та фінансово-розрахункового процесів, які в підсумку впливають на фінансову стійкість будівельних підприємств, що задіяні у будівництві. Впровадження сучасних методів контролю і управління заборгованістю у кожному будівельному проєкті, якими $є$ використання методів статистичного управління процесами, являється запорукою ефективної діяльності підприємства, що і визначає актуальність дослідження.

Аналіз останніх досліджень i публікацій. Аналізом ефективності використання оборотних активів будівельних підприємств займалися такі вчені, як Бєлєнкова О.Ю. [9-10], Ізмайлова К.В. [7-8], Запєчна Ю.О., Ковалева Л.О., Черноштан 0.0. [12], Шевченко Ю.О., Цифра Т.Ю., Боліла Н.В. [11], Москалюк Г.О. [13] та ін. Однак відсутність в економічній літературі єдиного підходу щодо визначення чинників впливу та управління на цій основі дебіторською заборгованістю, зумовило необхідність здійснення подальших досліджень у даному напрямі.

Варіабельність показників і параметрів характерна для будьякого інвестиційно-будівельного процесу, що пов'язаний із грошовими потоками. На процес можуть впливати випадкові і специфічні чинники, що обумовлює відхилення від плану. Завчасне виявлення таких чинників і своєчасне реагування $€$ запорукою запобігання банкрутства підрядних будівельних підприємств. Ефективним інструментом для контролю відхилень $€$ методи статистичного управління процесами (SPC) - широко розповсюдженого і потужного інструменту виробничого менеджменту, призначеного для безперервного моніторингу i діагностики будь-яких бізнес-процесів. Одним із ефективних методів SPC $\epsilon$ контрольні карти, призначені для виявлення відхилень фактичних параметрів процесу від планових.

Найбільш доступними методами управління процесами $\epsilon$ статистичні методи, серед яких слід виділити контрольні карти Шухарта, що дозволяють виявляти відхилення руху грошових коштів від плану. 
Контрольні карти Шухарта - це поєднання теорії ймовірностей і практичного досвіду, вони дуже ефективні для виявлення некерованою варіації будь-якого процесу. Перша контрольна карта Шухарта була опублікована в 1924 р., а до 1931 р. Шухарт завершив написання своєї першої монографії «Економічний контроль якості продукції» [5].

Контрольні карти можна розділити за двома ознаками [6]:

1. Контрольні карти на основі статистичних оцінок. До них віднесені контрольні карти для регулювання за кількісними ознаками (контрольна карта для середніх значень і розмаху - $(\bar{x} R)$, контрольна карта для медіани і розмаху - $(\overline{\mathrm{X}}-\mathrm{R})$, контрольна карта для окремих значень вимірюваних величин - (х)); контрольні карти для регулювання за якісними ознаками (контрольна карта для частки дефектних виробів, контрольна карта для числа дефектних виробів, контрольна карта для числа дефектів - з-карта, контрольна карта для числа дефектів, що припадають на одиницю виробу - uкарта); інші види контрольних карт (контрольна карта, що використовує граничні значення допуску, контрольна карта для середніх значень і середніх квадратичних відхилень, контрольна карта для крайніх значень, контрольна карта для змінного середнього і змінного розмаху).

2. Контрольні карти в залежності від сфери застосування.

Карти Шухарта застосовують на підприємствах для виявлення чинників якості продукції [5; 6], оцінки технологічних процесів [5; 6; 14; 15], для моніторингу та оцінки стану управління фінансами підприємств [2], оцінки ефективності і керованості показників економічної безпеки [3]. Відомо, що контрольні карти Шухарта широко використовують при контролі в різних галузях $[2-6 ; 14 ; 15]$.

Спроби контролю дебіторської заборгованості здійснено у праці [4], де автором використано карти Шухарта для наступних показників: коефіцієнт оборотності і період оборотності дебіторської заборгованості, співвідношення дебіторської та кредиторської заборгованості, коефіцієнт відволікання оборотних активів в загальну дебіторську заборгованість та середній рівень інвестування фінансових ресурсів у дебіторську заборгованість, але відхилення фактичних термінів і обсягів заборгованості від планових автором не визначалось.

Формулювання цілей статті (постановка завдання). Метою роботи $\epsilon$ вдосконалення контролю та управління дебіторською заборгованістю на основі статистичних методів управління процесом.

Методи дослідження. У якості об'єкта дослідження нами обрано систему управління дебіторською заборгованістю 
будівельного підприємства, що включає контроль надходжень і витрат грошових коштів у результаті операційної діяльності. У дослідженнях застосовані методи і прийоми статистичного управління процесами у відповідності до вимог [1]. В якості основного обраний статистичний метод контролю відхилень контрольні карти Шухарта. Розрахунок параметрів контрольних карт Шухарта проводили за методикою, представленою в [1].

Результати дослідження. Дебіторська заборгованість являє собою суму боргів, невиплачених підприємству партнерами, коли придбання товару (роботи послуги) та їх оплата не збігаються за термінами. Дебіторська заборгованість також виникає у процесі виробничої діяльності по заробітній платі, перед бюджетом тощо.

Управління дебіторською заборгованістю - потужний інструмент забезпечення економічної стійкості будівельного підприємства, оскільки занадто м'які умови розрахунків, відволікають кошти підприємства, а жорсткі можуть перешкоджати укладенню деяких договорів.

Розмір планової потреби в оборотних коштах, для визначення термінів і обсягів дебіторської заборгованості, розраховуємо за методикою, наведеною у роботі Ізмайлової К.В. [7] (рис. 1).

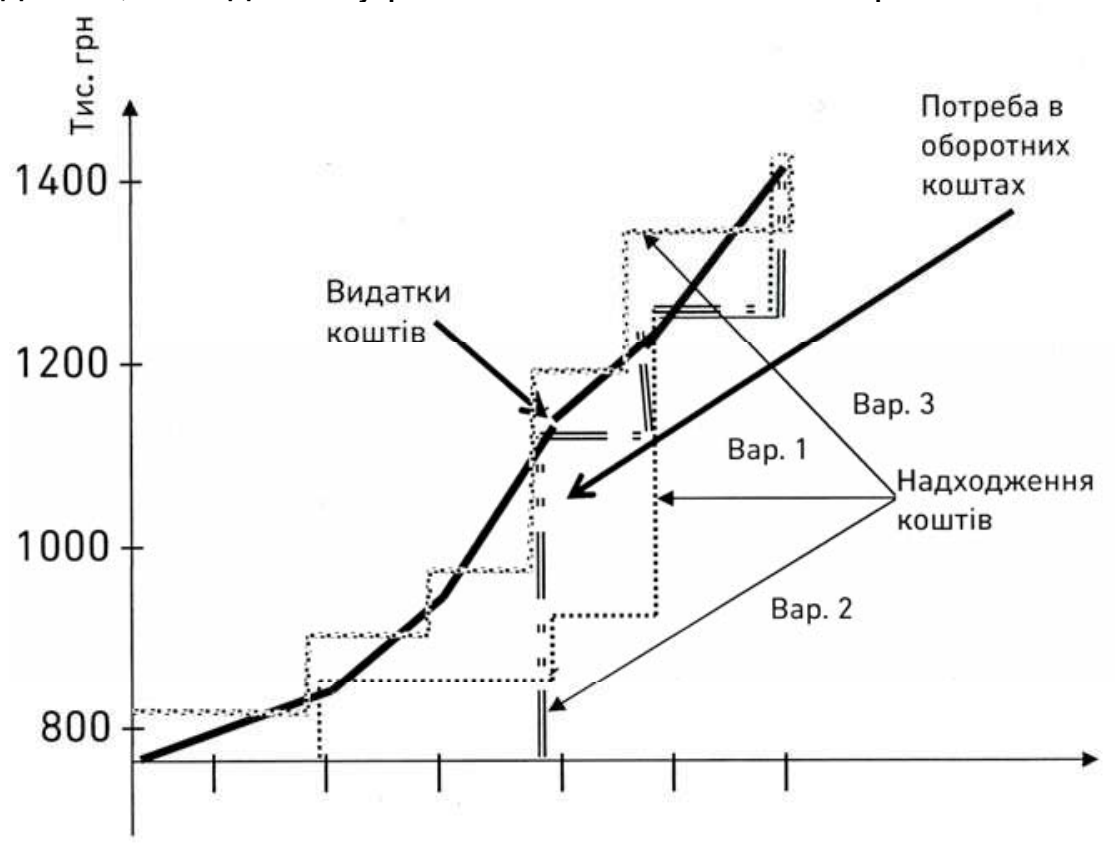

$$
\begin{aligned}
& \text { Умовні позначення: } \\
& 1 \text { - ий варіант розрахунків } \\
& 2 \text { - ий варіант розрахунків } \\
& 3 \text { - ій варіант розрахунків }
\end{aligned}
$$

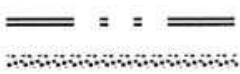

Рис. 1. Формування потреби оборотних коштів в залежності від умов розрахунків за виконані будівельні роботи [7, С. 37] 
Було застосовано різні види контрольних карт Шухарта за кількісною ознакою для показників відхилення обсягів дебіторської заборгованості від плану ( $\triangle$ ДЗ). Для контролю за $\Delta$ ДЗ застосовано карти індивідуальних значень (Х-карта) і ковзних розмахів (Rmкарта). Rm-карта $€$ індикатором мінливості процесу, наочно виявляючи будь-яку небажану варіацію.

Для усунення кореляції визначаються не фактичні і планові обсяги дебіторської заборгованості за товари, роботи, послуги, а прирости до попереднього періоду. У період із березня 2019 р. по березень 2020 р. один раз на місяць визначались відхилення фактичної потреби у оборотних коштах будівельного підприємства від планової (табл. 1).

Таблиця 1

Відхилення фактичних обсягів ДЗ від планових, \%

\begin{tabular}{|l|r|r|r|r|r|r|r|r|r|r|r|r|r|}
\hline $\begin{array}{l}\text { No } \\
3 / n\end{array}$ & 1 & 2 & 3 & 4 & 5 & 6 & 7 & 8 & 9 & 10 & 11 & 12 & 13 \\
\hline $\mathrm{X}$ & $8,4 \%$ & $16,1 \%$ & $13,6 \%$ & $17,7 \%$ & $1,7 \%$ & $16 \%$ & $14 \%$ & $1 \%$ & $9,7 \%$ & $11,8 \%$ & $6,4 \%$ & $7,3 \%$ & $8,9 \%$ \\
\hline $\mathrm{R}, \%$ & & $7,7 \%$ & $2,5 \%$ & $4 \%$ & $15,9 \%$ & $14,3 \%$ & $2,1 \%$ & $13 \%$ & $8,8 \%$ & $2 \%$ & $5,4 \%$ & $0,9 \%$ & $1,6 \%$ \\
\hline
\end{tabular}

Визначимо $\bar{X}$ і $\bar{R}$ :

$$
\begin{aligned}
& \bar{X}=\frac{8,4+16,1+\cdots+8,9}{13}=10,2 \% ; \\
& \bar{R}=\frac{7,7+2,5+\cdots+1,6}{13}=6,5 \% .
\end{aligned}
$$

Створимо контрольну карту для ковзних розмахів $\mathrm{R}$ (рис. 2).

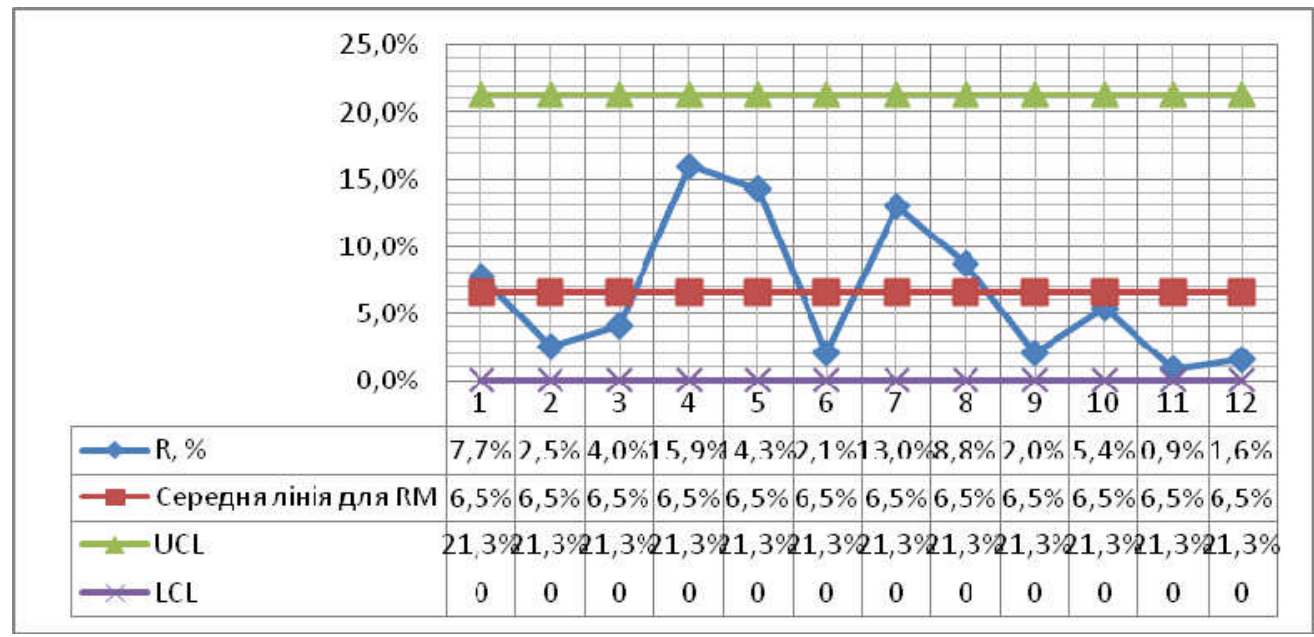

Рис. 2. Контрольна карта для ковзних розмахів $\mathrm{R}$ 
Лінії контрольної карти:

Центральна лінія $\mathrm{CL}=\mathrm{R}=6,5 \%$

$\mathrm{U}_{\mathrm{CL}}=\mathrm{D} 4^{*} \bar{R}=3,267^{*} 6,5 \%=21,3 \%$.

$\mathrm{L}_{\mathrm{CL}}=\mathrm{D} 3 * \bar{R}=0 * 6,5 \%=0$

Значення коефіцієнтів D3 і D4 визначають по таблиці 2 для п = 2 [1]. Оскільки карта розмахів показує стан статистичної керованості, може бути побудована контрольна карта індивідуальних значень (рис. 3).

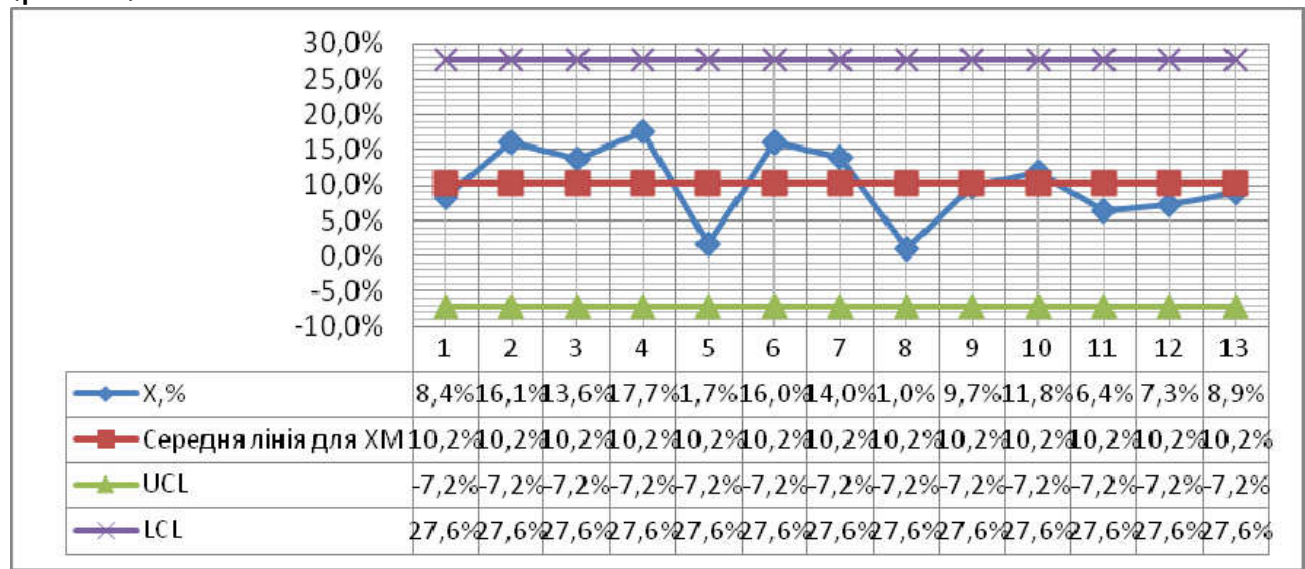

Рис. 3. Контрольна карта індивідуальних значень X

Лінії контрольної карти:

Центральна лінія $\mathrm{CL}=\mathrm{X}=10,2 \%$

$\mathrm{U}_{\mathrm{CL}}=\mathrm{X}+\mathrm{A} 3 * \bar{R}=10,2+2,66 * 6,5 \%=27,6 \%$.

$\mathrm{L}_{\mathrm{CL}}=\mathrm{X}-\mathrm{A} 3^{*} \bar{R}=10,2-2,66 * 6,5 \%=7,2 \%$

3 рисунків видно, що всі значення досліджуваних показників не виходять за межі регулювання, немає серій і трендів. Це показує, що не виявлено виникнення особливих причин, які можуть вплинути на якість процесу. Отже, процес надходження коштів можна вважати стабільним. У разі виявлення виходу процесу з-під контролю необхідно буде аналізувати причини нестабільності і вживати заходів щодо його регулювання, а значення кордонів перераховувати. Отримані нами контрольні кордони для представлених карт можуть використовуватися на підприємстві для подальшого моніторингу відхилень дебіторської заборгованості.

Висновки та пропозиції подальших досліджень. У даній роботі було запропоновано для вдосконалення дослідження процесу контролю дебіторської і кредиторської заборгованостей застосовувати контрольні карти Шухарта.

Запропонований підхід оптимізує виявлення виходу процесу 3 керованого стану, дозволяє оцінювати характер мінливості, 
допомагає виявленню особливих причин, дає можливість зафіксувати як невеликі, так і значні зміни грошових потоків i оперативно, при необхідності, втручатися в процес, не допускаючи виникнення безнадійної заборгованості.

1. ДСТУ ISO 7870-2:2016. Статистичний контроль. Карти контрольні. Частина 2. Карти Шухарта (ISO 7870-2:2013, IDT). [Чинний від 2016-09-01]. URL: http://document.ua/statistichnii-kontrol_-karti-kontrolni_-chastina-2_-karti-shstd37191.html_(дата звернення: 20.05.2020). 2. Бондаренко О. С. Розвиток фінансів підприємств в умовах логістизації економіки : дис. ... д-ра екон. наук. Київ, 2017. URL: https://knute.edu.ua/file/Mg==/15e6f75f1162476db3c 844d55091d6e8.pdf (дата звернення: 20.05.2020). 3. Кучур М. Г. Фінансова безпека суб'єктів підприємництва виноробної галузі України : дис. ... д-ра екон. наук : 08.00.08. Краматорськ, 2018. URL: http://www.dgma.donetsk.ua/docs/nauka/vcheni_rady/12.105.03/73dis_.pdf (дата звернення: 20.05.2020). 4. Сметанкін А. С. Аналіз дебіторської заборгованості підприємства «пк - енергомонтажсервіс» за допомогою карт Шухарта. Фінанси очима студентів: зб. матеріалів студентської науково-практичної конференції (16-18 травня 2018 року). Харків : ХНЕУ ім. С. Кузнеця, 2018. С. 123-124. 5. Статистическое управление процессами: оптимизация бизнеса с использованием карт Шухарта / Дональд Уилер, Дэвид Чамберс ; пер. с англ. М. : Альпина Бизнес Букс, 2009. 409 с. 6. Саката Сиро. Практическое руководство по управлению качеством / пер. с 4-го японского издания С. И. Мышкиной ; под ред. В. И. Гостева. М. : Машиностроение. 1980. 215 с. 7. Ізмайлова К.В. Економічне обґрунтування умов розрахунків за будівельну продукцію. Економіка будівництва. 2005 р. Вип. 3. С. 36-39. 8. Ізмайлова К.В. Екологічний супровід запасів як чинник ефективності використання оборотних засобів будівельного підприємства. Шляхи підвищення ефективності будівництва в умовах формування ринкових відносин. 2018. Вип. 36. С. 3-7. 9. Бєлєнкова О.Ю. Управління оборотними активами будівельного підприємства як засіб отримання конкурентних переваг. Шляхи підвищення ефективності будівництва в умовах формування ринкових відносин : зб. наук. праць. 2015. Вип. 33. С. 10-17. 10. Бєлєнкова О. Ю. Вплив сезонних коливань на оборотні активи будівельного підприємства. Інвестиції: практика та досвід. 2015. № 19. С. 4853. 11. Шевченко Ю. С., Боліла Н. В., Цифра Т. Ю. Ефективне використання оборотних коштів будівельного підприємства як фактор економічної безпеки. Шляхи підвищення ефективності будівництва в умовах формування ринкових відносин. 2020. № 44. С. 133-146. 12. Запєчна Ю. О., Ковалєва Л. О., Черноштан 0. 0. Оборотні кошти будівельних підприємств та специфіка управління ними. Шляхи підвищення ефективності будівництва в умовах формування ринкових відносин. 2018. №38. С. 157-165. 13. МоскалюкГ. О. Облік та контроль дебіторської заборгованості: існуючі проблеми та шляхи їх вирішення. Вісник Національного університету «Львівська політехніка». 2012. №721. С. 173-179. URL: http://ena.lp.edu.ua:8080/bitstream/ntb/12736/1/31_167-79_Vis721 menegment.pdf (дата звернення: 20.05.2020). 14. Роскладка А. А., Божко В. І. Методика діагностики та контролю швидкості доступу до мережі інтернет. Науковий вісник Херсонського державного університету. $2014 . \quad$ Ч. 6. Вип.9. С. 239-242. URL: http://www.ej.kherson.ua/journal/economic_09/325.pdf (дата звернення: 20.05.2020). 15. Дядюра К. О., Нагорний В. М. Удосконалення методу контрольних карт на основі класифікуючої функції. Сучасні технології в машинобудуванні, 2013. Вип. 8. C. 218-227. 16. Shewhart W. A. Economic Control of Manufactured Product. D. Van 
Серія «Економічні науки»

Випуск 2(90) 2020 p.

Norstrand, Co, New York, 1931. P. 501.

\section{REFERENCES:}

1. DSTU ISO 7870-2:2016. Statystychnyi kontrol. Karty kontrolni. Chastyna 2. Karty Shukharta (ISO 7870-2:2013, IDT). [Chynnyi vid 2016-09-01]. URL: http://document.ua/statistichnii-kontrol_-karti-kontrolni_-chastina-2_-karti-sh-

std37191.html (data zvernennia: 20.05.2020). 2. Bondarenko 0. S. Rozvytok finansiv pidpryiemstv $v$ umovakh lohistyzatsii ekonomiky : dys. ... d-ra ekon. nauk. Kyiv, 2017. URL: https://knute.edu.ua/file/Mg==/15e6f75f1162476 db3c844d55091 d6e8.pdf (data zvernennia: 20.05.2020). 3. Kuchur M. H. Finansova bezpeka subiektiv pidpryiemnytstva vynorobnoi haluzi Ukrainy: dys. ... d-ra ekon. nauk: 08.00.08. Kramatorsk, 2018.

URL: http://www.dgma.donetsk.ua/docs/nauka/vcheni_rady/12.105.03/73dis_.pdf (data zvernennia: 20.05.2020). 4. Smetankin A. S. Analiz debitorskoi zaborhovanosti pidpryiemstva «pk - enerhomontazhservis» za dopomohoiu kart Shukharta. Finansy ochyma studentiv: zb. materialiv studentskoi naukovo-praktychnoi konferentsii (16-18 travnia 2018 roku). Kharkiv: KhNEU im. S. Kuznetsia, 2018. S. 123-124. 5. Statisticheskoe upravlenie protsessami: optimizatsiya biznesa s ispolzovaniem kart SHuharta / Donald Uiler, Devid CHambers ; per. s angl. M. : Alpina Biznes Buks, 2009. 409 s. 6. Sakata Siro. Prakticheskoe rukovodstvo po upravleniyu kachestvom / per. s 4-go yaponskogo izdaniya S. I. Myishkinoy; pod red. V. I. Gosteva. M. : Mashinostroenie. 1980. 215 s. 7. Izmailova K. V. Ekonomichne obgruntuvannia umov rozrakhunkiv za budivelnu produktsiiu. Ekonomika budivnytstva. 2005 r. Vyp. 3. S. 36-39. 8. Izmailova K.V. Ekolohichnyi suprovid zapasiv yak chynnyk efektyvnosti vykorystannia oborotnykh zasobiv budivelnoho pidpryiemstva. Shliakhy pidvyshchennia efektyvnosti budivnytstva $v$ umovakh formuvannia rynkovykh vidnosyn. 2018. Vyp. 36. S. 3-7. 9. Bielienkova O. Yu. Upravlinnia oborotnymy aktyvamy budivelnoho pidpryiemstva yak zasib otrymannia konkurentnykh perevah. Shliakhy pidvyshchennia efektyvnosti budivnytstva $v$ umovakh formuvannia rynkovykh vidnosyn: zb. nauk. prats. 2015. Vyp. 33. S. 10-17. 10. Bielienkova O. Yu. Vplyv sezonnykh kolyvan na oborotni aktyvy budivelnoho pidpryiemstva. Investytsii : praktyka ta dosvid. 2015. № 19. S. 4853. 11. Shevchenko Yu. S., Bolila N. V., Tsyfra T. Yu. Efektyvne vykorystannia oborotnykh koshtiv budivelnoho pidpryiemstva yak faktor ekonomichnoi bezpeky. Shliakhy pidvyshchennia efektyvnosti budivnytstva $v$ umovakh formuvannia rynkovykh vidnosyn. 2020. № 44. S. 133-146. 12. Zapiechna Yu. O., Kovalieva L. O., Chernoshtan 0. 0. Oborotni koshty budivelnykh pidpryiemstv ta spetsyfika upravlinnia nymy. Shliakhy pidvyshchennia efektyvnosti budivnytstva $v$ umovakh formuvannia rynkovykh vidnosyn. 2018. №38. S.157-165. 13. Moskaliuk H. O. Oblik ta kontrol debitorskoi zaborhovanosti: isnuiuchi problemy ta shliakhy yikh vyrishennia. Visnyk Natsionalnoho universytetu «Lvivska politekhnika». 2012. № 721. S. 173-179. URL: http ://ena.lp.edu.ua:8080/bitstream/ntb/12736/1/31_167-

179_Vis721menegment.pdf (data zvernennia : 20.05.2020). 14. Roskladka A. A., Bozhko V. I. Metodyka diahnostyky ta kontroliu shvydkosti dostupu do merezhi internet. Naukovyi visnyk Khersonskoho derzhavnoho universytetu. 2014. Ch. 6. Vyp. 9. S. 239-242. URL: http://www.ej.kherson.ua/journal/economic_09/325.pdf (data zvernennia: 20.05.2020). 15. Diadiura K. O., Nahornyi V. M. Udoskonalennia metodu kontrolnykh kart na osnovi klasyfikuiuchoi funktsii. Suchasni tekhnolohii $v$ mashynobuduvanni. 2013. Vyp. 8. S. 218-227. 16. Shewhart W. A. Economic Control of Manufactured Product. D. Van Norstrand, Co, New York, 1931. P. 501. 
Stetsenko S. P. [1; ORCID ID : 0000-0003-1439-3581],

Doctor in Economics, Associate Professor, Department of Construction

Economics,

Bolila N. V. [1; ORCID ID: 0000-0002-3353-8347], Senior Lecturer, Department of Construction Economics

Ivanchenko A. M. [2; ORCID ID: 0000-0002-1571-7173], Candidate of Economics (Ph.D.), Associate Professor

\author{
${ }^{1}$ Kyiv National University of Construction and Architecture, Kiev \\ ${ }^{2}$ National University of Water and Environmental Engineering, Rivne
}

\title{
ANALYTICAL EVALUATION AND CONTROL OF RECEIVABLES OF CONSTRUCTION ENTERPRISES USING CONTROL CARDS
}

The work is devoted to the analysis and control of receivables of construction contractors on the basis of statistical methods of production management. To solve this scientific problem, the method of Schuhart's control charts is used, which is based on statistical processing of data on deviations of actual terms and amounts of receivables from their planned values. Based on the analysis of the nature of deviations, conclusions are made about the nature of deviations (random or not) and management decisions are made. It is proposed to control the receivables of construction contractors in terms of contract prices as part of construction contracts and additional agreements (planned indicators), actual revenues and expenditures and calculation of planned and actual needs of the company in working capital. The control is carried out by indicators : terms of receipt of money and volumes of need for working capital under each construction contract. This approach allows a differentiated approach to the causes of deviations from the plan. The paper analyzes the receivables of the construction company and proposes to control deviations from the plan with the help of Schuhart control maps, which allow not only to detect deviations, but also to determine the factors of influence such as random and specific. This approach allows you to reliably determine the factors of influence, to predict the risks of loss of financial stability and the consequences of their action for the economic security of the construction company. The application of a well-known and widespread method of analysis in a new area, namely - to control receivables. In the process of analysis it was found that the proposed approach allows to control deviations of terms and the level of receivables, to identify random and specific factors that affect deviations from the plan. Some results and conclusions of the article can be used by construction companies, as well as companies in other industries, in the case of their appropriate adaptation, for the analysis and control of receivables. 
Keywords: receivables; current assets; construction company; economic stability; construction.

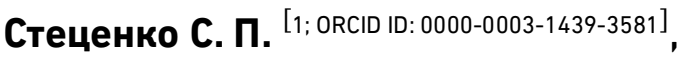
д.э.н., доцент кафедры экономики строительства,

Болила Н. В. [1; ORCID ID: 0000-0002-3353-8347], ст. преподаватель кафедры экономики строительства

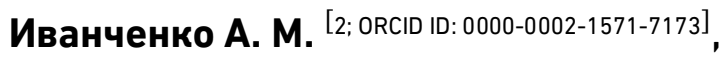
к.э.н., доцент

${ }^{1}$ Киевский национальный университет строительства и архитектуры, г. Киев ${ }^{2}$ Национальный университет водного хозяйства и природопользования, г. Ровно

\section{АНАЛИТИЧЕСКАЯ ОЦЕНКА И КОНТРОЛЬ ДЕБИТОРСКОЙ ЗАДОЛЖЕННОСТИ СТРОИТЕЛЬНЫХ КОМПАНИЙ С ПОМОЩЬЮ КОНТРОЛЬНЫХ КАРТ}

Работа посвящена проведению анализа и контроля дебиторской задолженности подрядных строительных предприятий на основе статистических методов производственного менеджмента. Для решения данной научной задачи применен метод контрольных карт Шухарта, основанный на статистической обработке данных по отклонению фактических сроков и объемов дебиторской задолженности от их плановых значений. На основе анализа характера отклонений делаются выводы о характере отклонений (случайные или нет) и принимаются управленческие решения. Предложено проводить контроль дебиторской задолженности подрядных строительных предприятий в разрезе договорных цен в составе строительных контрактов и дополнительных соглашений (плановые показатели), фактических поступлений и расходов, расчета плановой и фактической потребности предприятия в оборотных средствах. Контроль осуществляется по показателям: сроки поступления денежных средств и объемы потребности в оборотных средствах по каждому строительному контракту. Такой подход позволяет дифференцированно подходить к причинам возникновения отклонений от плана. В работе проанализировано дебиторскую задолженность строительного предприятия и предложено проводить контроль отклонений от плана с помощью контрольных карт Щухарта, которые позволяют не только выявлять отклонения, но и определять факторы влияния такие как случайные и специфические. Такой подход позволяет достоверно определить факторы влияния, спрогнозировать риски потери финансовой устойчивости и последствия их действия для экономической безопасности строительного предприятия. Осуществлено применение известного и широко распространенного метода анализа в новой 
области, а именно - для контроля дебиторской задолженности. В процессе анализа выявлено, что предложенный подход позволяет осуществлять контроль отклонений сроков и уровня дебиторской задолженности, выявлять случайные и специфические факторы, которые влияют на отклонение от плана. Отдельные результаты и выводы статьи могут быть использованы строительными предприятиями, а также предприятиями других отраслей, в случае их соответствующей адаптации, для анализа и контроля дебиторской задолженности.

Ключевые слова: дебиторская задолженность; оборотные активы; строительное предприятие; экономическая устойчивость; строительство.

Стаття надійшла до редакції 20.06.2020 р. 